(昭和 23 年 3 月 10 日受理)

\title{
蛋白質の利用に關する研究 (III)
}

\section{第 3 報 牛乳カゼインの膨潤について}

䁷年製油清水工場宮崎 泰顯

\section{緒言}

高分子物質の膨潤に關七ては瀻維部門に於て海外で は古くからの研究者 J. R. Katz を始めとして K. H ess, C. Trogus, J. B. Speakman 等々の研究があり 國內では租父江氏,1" 櫻田氏,2) 井上氏,8) 等の研究があ る。又合成樹脂については井上氏，3鶴田氏，( の研究 がある。

上記の研究にて得大理論は同じ高分子物貿たる牛乳 カぜインの膨潤にも原則的に雔用されるべきであり，

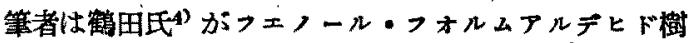
脂の研究に際して利用した操作は本凡，簡單であるが 定性的に膨潤過程を追究するに有力な武器たる所謂沈 降容程法によつて大豆蛋白質の膨润溶解の研究の前提

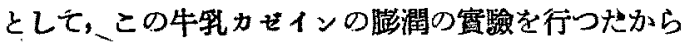
以下その結果を報告する。

\section{試料及び貫驗方法}

竇驗に使用せる試料カゼインは某社製市販品で分析 結果は第1表に示捅りであつた。

\begin{tabular}{|c|c|c|}
\hline & 第 1 表 & カゼインの分析結果 \\
\hline & 分 ， & $9.94 \%$ \\
\hline & そび不能物 & 徽弱なる乳莫老有 L \\
\hline & & 不溶物存在せず \\
\hline 酸 & 㵋 & 9.24 \\
\hline 脂 & 䀡 & $0.61(0.68)$ \\
\hline 窒 & 素 & $12.75 \cdot(14.16)$ \\
\hline 灰 & 分 & $1 \cdot 14(1.27)$ \\
\hline & 粉 & 混在はず \\
\hline
\end{tabular}

括弧内住無水陚料儿對する蜘值

本分析は主として田中，安藤著「化學工業試驗 法」とよる

實驗に使用せる沈降容積法は有效長さ約 $230 \mathrm{~mm}$ の 目盛付きガラス管 (內俓 $8 \mathrm{~mm}$ ) に試料 $1 \mathrm{~g}$ を秤取し試

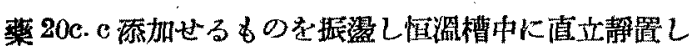

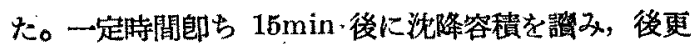
に取出し层盜し再び恒溫槽中に直立静置し $15 \mathrm{~min}$ 後

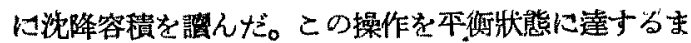

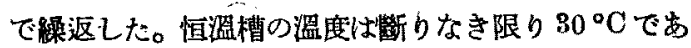
つた。ガラス管は恒溫槽の水中に出來る丈け深く入れ

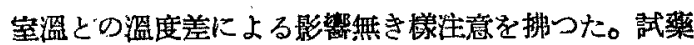

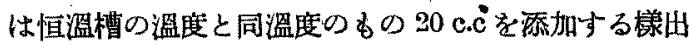
來る文け注意を拂つた。吸液量は膨潤力ゼインを取出

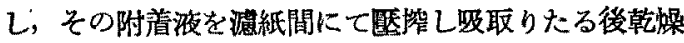
(100 105 ${ }^{\circ} \mathrm{C} ， 3 \mathrm{hr}$ ) して前後の差より求めた。

使用せる試藥は㦼酸, 醋酸, 蒸溜水, メキルアル ール, エチルアルンール, アセトン, エーテル,トル オール，キシロール，四監化炭素であつた。

\section{䨘駼結果及び其の考察}

R. Fricke, J. Lüke ${ }^{5)}$ はカぜインの水膨潤について

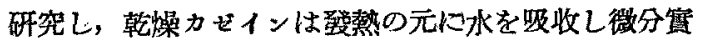

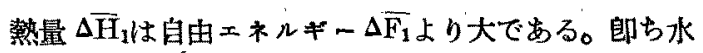
のエントロピーが隇少することを見出した。このこと は水は先つ或る一定の場所に引力によつて固着される ことを證明するすのである。少含水率 $40 \%$ で $\overline{\mathrm{F}_{1}}$ と $\overline{\mathrm{H}_{1}}$ は同一になり，それ以後主として混合ェントロピー效 果による擴散現象が生ずる。この擴散現象については 後述する䗋酸, 醋酸の異常膨潤の例を考へれば，井上

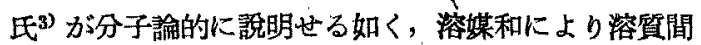

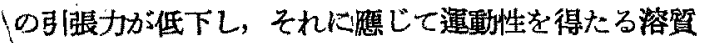
分子がとり得る立體配位に上つ飞決る分子間空隐に抱 含される液體と考へる方が說明しやすいで出ろ.5。

さて第 2 表に測定吸液量及び桑田氏著「溶劑」，A. Weissberger, H. Proskauer 著, 井本, 户田氏譯「有機 溶劑」より引用せる分子容積, 會合度, 誘電恒数, 双 楀子能率を示した。吸液量は無水カぜンン100g 當り のmol 數で示したが, 醋酸〜アセトンではかせインの 含有水分はこれを無視して吸液量は全部試燕として計 算した。エーテル〜四整化炭素ではカゼインの含有水 分意差可いて馀算した。 
第 2 表

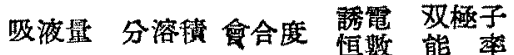
$\left(\begin{array}{c}\mathrm{mol} / 100 \mathrm{~g} \text { 無 } \\ \text { 水カぜや }\end{array}\right)$

\begin{tabular}{|c|c|c|c|c|c|}
\hline 蟻酸 $(80 \%)$ & $\begin{array}{l}\text { 一橙に } \\
\text { 当摆 }\end{array}$ & 37.7 & 3.62 & 57 & 1.19 \\
\hline 醌 酸 & 16.38 & 57.1 & 3.62 & 9.7 & 1.04 \\
\hline 水 & 5.04 & 18 & 3.68 & 80 & 1.87 \\
\hline $\begin{array}{l}\times \neq x \\
>x=-x\end{array}$ & 1.02 & 40.5 & 3.43 & 39.2 & 1.87 \\
\hline $\begin{array}{l}\mp \neq \\
\Gamma \mu-n\end{array}$ & 0.84 & 58.3 & 2.74 & 25.8 & 1.696 \\
\hline 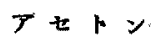 & 0.17 & 78.3 & 1.26 & 21.4 & 2.74 \\
\hline$x-\mp u$ & 0.049 & 108 & 1.00 & 4.33 & 1.15 \\
\hline トyォーx & 0.009 & 106 & - & 2.39 & 0.4 \\
\hline$\neq シ ロ ー ル$ & 0.029 & $1228(\mathrm{~m})$ & 一 & $2.88(\mathrm{~m})$ & $0.34(\mathrm{~m})$ \\
\hline 四䁍化炭素 & 0.011 & 99.8 & - & 2.24 & 0 \\
\hline
\end{tabular}

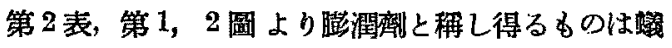
酸, 醋酸, 水, $\times$ チアアルコール, エキルアルコール

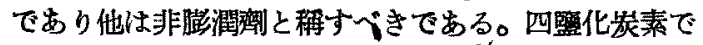
はカぜインが表面に浮いたため國示じなかつた。酷酸 の場合は侸朝まて約15時聞故置せるときの沈積量です \%。
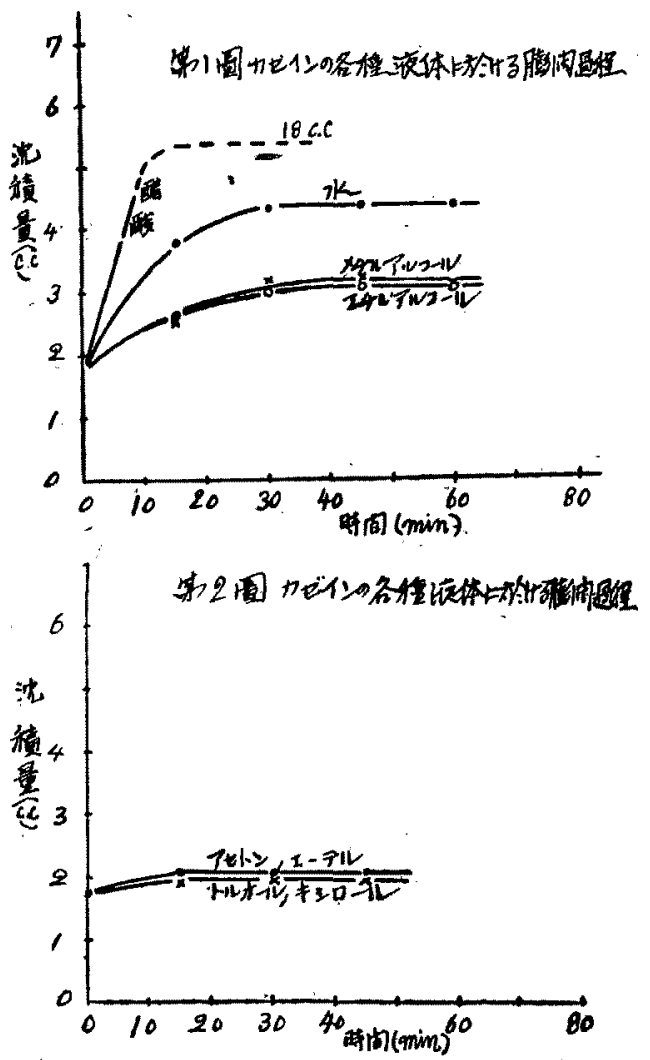

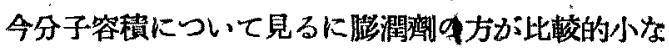

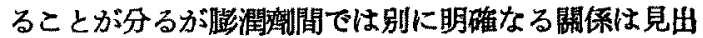
し得ない。唯だアルコールのみについて考へれば, 模

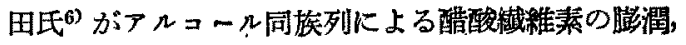
鶴田(4) $\therefore$ フォルムアルデとド澍脂の膨潤の際に得た結果の如 くこの場合も炭录數の增加と共に膨潤度は減少すへくく， このことは炭素數の㙘加と共に分子容䅡る堌加しそれ に從のて膨潤度は減少与るとも云ひ得るですら5。上 記のことは蜜驗回數少くてはつきり結論を艺出し得ない 方脂肪酸の場合にも充分考へられることてあら5。

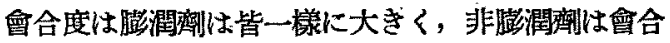
性があつてす極めて小さい。给アルコール同族列のみ について考へれば龙素數の堌加と共に會合度は減少す

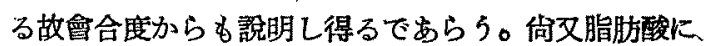
しても同栐でら5。

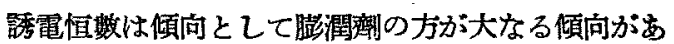
りこのことは双樰子能萃についてす云び得るととた ある。アセトンは異常大の双極子能率をるらながら例

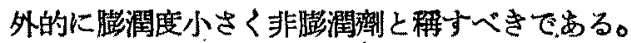

份以上检討した数値的には他に比して特異な数值を

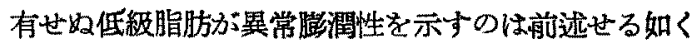
“蛋白溶質分子が取り得る立體配位によつて決る分子間

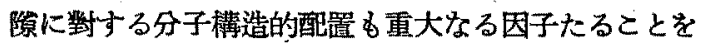
示するのであらら。
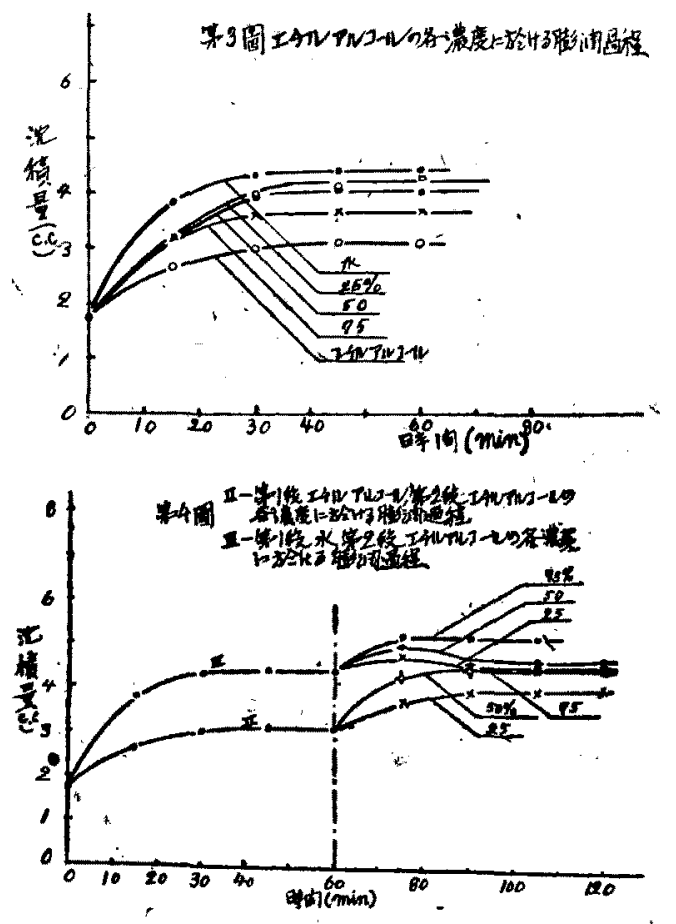

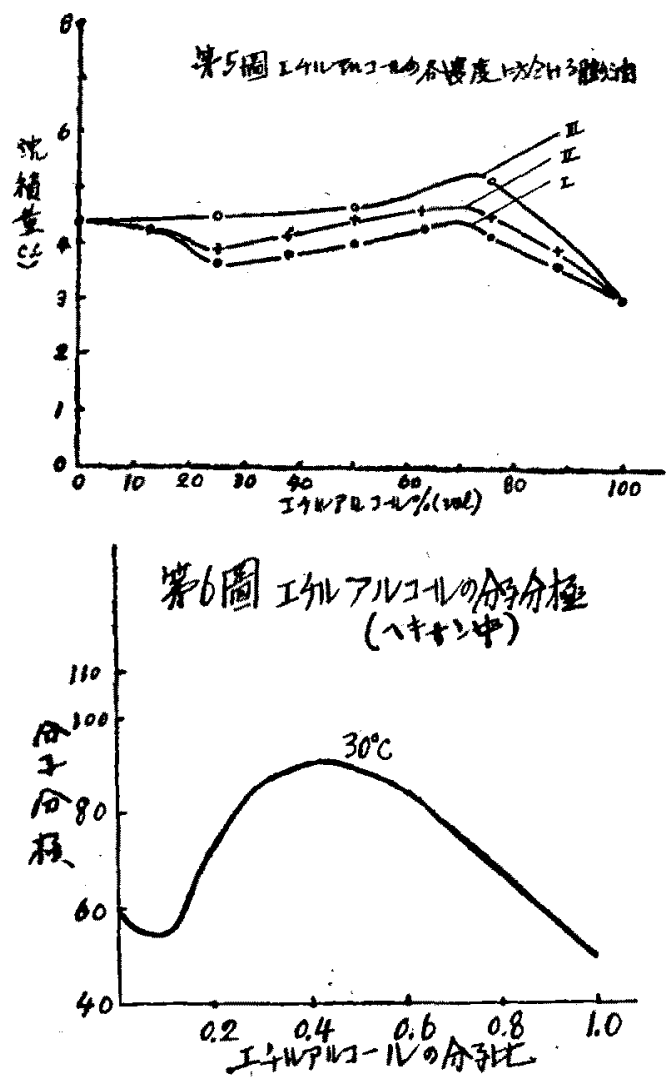

エチルアルュールの各濃度に於ける膨潤無水の場合

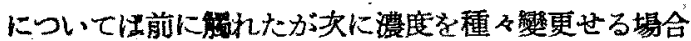
Кついて檢討した。

第3圖は最初より各清度のアルコールについて签驗 せるすのであるが，第 4 圖曲線 IIは最初アルコールに て本衡に到らせしめ後上澄液を取出し代りに蒸溜水を 同量 $\left(30^{\circ} \mathrm{C}\right)$ 㴽加した場合で岕り，曲線回は最初水に て平衛に到せしめ後上澄液を取出し代りにアルコール を同量 $(30$ :C) 添加せるるのでする。

曲線】第 2 段の膨潤に於て $50 \% ， 25 \%$ 濃度の場合 に見る如く椣大值の存なるのは吸收水分にアルコーヘ か浊く引き付けられ为に反對に對蛋白分子との親和力 減した或部の水分子が脫離寸るものと考へられる。 75\%の場合極大值が表はれずに本衡に達するのは或部 の水分子か䩕蛋白分子との親和力を消失しても，この 水分子と重合㓠熊にあるァルコール分子の親和力大な るため餘り䐋溶媒和現象が起ら 第 5 圆曲線 Iは第 3 圖よ、り，曲線 II，【江第 4 圖曲線 II【上り求めた平䘖沈䅡量である。第 5 圖に示す如 き曲線の表はれる原因は第 6 圆に示さ如くアルコール
の分子分極曲線》゙が第5 圖と傾向の全く一教すること 及び分子分極曲線より推定される分子の會合狀態を考 八れば梅性論的に說明されるで告らら。

アセトンの各澧㛺に於ける膨潤第 7 圖は第5 圆に相 栄するものであり，エチルアルコールとは全然珙つた

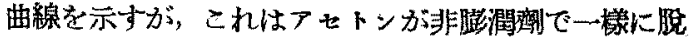
溶媒和作用定すこをを考へれば當然でする。

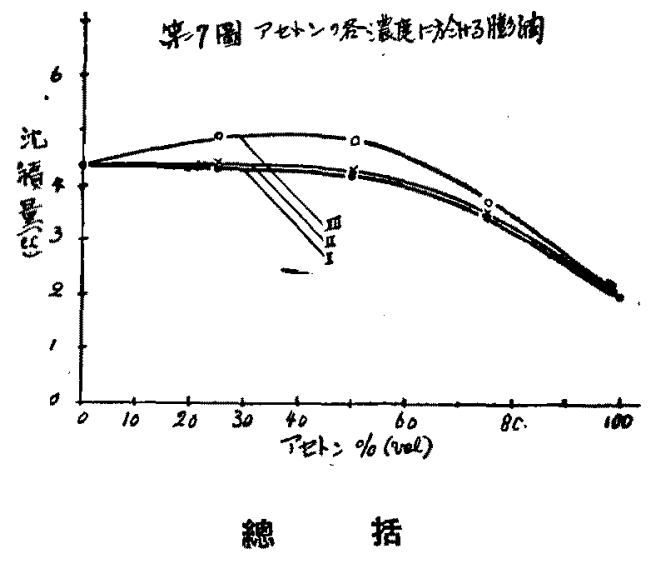

沈降容積法によつて牛乳カぜインの膨潤過程を洎究

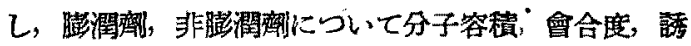
電恒數，双極子能隼の點よりも檢討した。亦ェチルフ

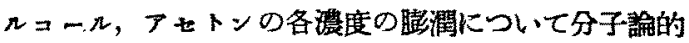
立堨より檢討した。

\section{文献}

1）租父江寬，戊工，昭 9.9.100，222. 工化，昭912, 37,1669

2) 贸田一郎, 鉿木庄八, 工化，昭 6-12. 34 1275;

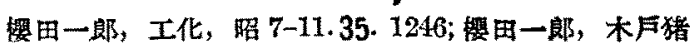
一郎, 工化, 昭 8-12. 36. 1576

3）井上幸彥，本誌，昭19-9.1. 563，572

4) 倠田四郎, 杉田收, 工化, 昭 15-10. 43.719；音 谷通，鹤田四郎，日化，昭21-1. 67.26

5) R. Fricke, J. Lüke, Z. Electrochem, 1930. 36. 309; Meyer-Mark, "Hochpolymere Chemie," II ,558

6）被田一郎，理研報，昭 6.10.819; Koll.Z., 1929. 48. 278

7) C. P. Smyth, W. N. Stoopes, J. Am, Chem. Soc., 1929. 51. 3312；棸田勉 “溶剂”, 85

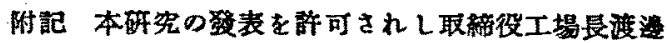
武市氏，研究部長萩原朋正氏に對し深詂する。 